\title{
Természetes hatóanyagok a májterápiában
}

\author{
Blázovics Anna dr. \\ Semmelweis Egyetem, Gyógyszerésztudományi Kar, Farmakognóziai Intézet, Budapest
}

\begin{abstract}
Az orvostudomány és mindazok a társtudományok, amelyek az egészség megőrzését és a betegségek leküzdését hivatottak kutatni, az 1930-as évek második felétől hihetetlen eredményeket értek el, és beláthatatlan távlatokat nyitottak meg a jövő generációi számára. Az 1980-as évektól kezdődően a természetes eredetű növényi hatóanyagok kutatása területén is szignifikáns eredmények születtek a különböző kórképek kapcsán felismert szabad gyökös károsodások kivédésére. A szerteágazó kutatások egyik fontos területe a táplálkozás szempontjából jelentős bioaktív molekulák felismerése, szerkezetük és hatásuk összefüggésének felderítése, valamint ezeknek az ismereteknek a birtokában a helyes étkezési szokások kialakítása, különös tekintettel a betegségekkel küszködő emberek számára. Az elmúlt évtizedek alatt a népgyógyászati megfigyelésektól számos növényi hatóanyag esetében eljutottunk a hatásmechanizmus molekuláris biológiai igazolásáig. Orv. Hetil., 2015, 156(47), 1888-1891.
\end{abstract}

Kulcsszavak: flavonoidok, antocianinok, hidroxi-fahéjsav-származékok, májterápia

\section{Natural bioactive agents in liver therapy}

\begin{abstract}
Medical science alongside with other sciences, aiming to preserve health and combat diseases, has evolved significantly since the late 1930s. It has reached incredible results and opened up unpredicted perspectives for future generations to come. From the 1980s significant results also emerged from researching natural plant active ingredients for the prevention of damage from free radicals which were discovered in different symptoms. One of the important areas of research is the recognition of significant bioactive molecules from the aspects of food consumption, alongside the detection of their effect in the context of their structure. It is also important that by possessing these data it is possible to develop correct food consumption habits, especially for people who are suffering from diseases. Through the decades we came a long way from folk medicine observations to molecular, biological justification of effect mechanisms.
\end{abstract}

Keywords: flavonoids, anthocyanins, hydroxycinnamic acid derivatives, liver therapy

Blázovics, A. [Natural bioactive agents in liver therapy]. Orv. Hetil., 2015, 156(47), 1888-1891.

(Beérkezett: 2015. augusztus 18.; elfogadva: 2015. szeptember 23.)

\section{Rövidítések}

AP-1 = aktivált protein- 1 ; COX-2 = ciklooxigenáz- $2 ;$ LOX = lipoxigenáz; MAPK = mitogénaktivált proteinkináz; $\mathrm{NF}-\kappa \mathrm{B}=$ nuclear factor kappa-B; $\mathrm{NO}=$ nitrogén-monoxid; PI3K/Akt = foszfoinozitol-3-kináz; VEGF = vascularis endothelialis növekedési faktor

A korai kutatások különös jelentőséget tulajdonítottak a szabadgyök-befogó, scavenger molekuláknak, de hamarosan kiderült, hogy az antioxidáns tulajdonság önmagában nem elegendő a betegségek leküzdésére, sőt az antioxidánsok túlzott mértékű fogyasztása miatt prooxidáns hatás jelentkezhet, valamint a redox-homeosztázis sérül, és az antioxidáns enzimaktivitások jelentős mértékben visszaszorulnak, mintegy védekezve a szervezet számára nélkülözhetetlen szabadgyök-szint megtartása érdekében $[1,2]$. A kutatások eredményei egyértelmúvé tették, hogy a különböző molekulaszerkezetű antioxidánsok és az antioxidáns tulajdonságú vitaminok, valamint a redox-homeosztázisban szerepet játszó ,jolly joker” fémes elemek megváltoztathatják a jelátviteli utakat, befolyásolhatják a sejtek szaporodását vagy apoptózisát, apoptózis hiányában pedig tumoros folyamatokat indukálhatnak $[3,4]$. 


\section{Fenolos vegyületek}

A gyógynövények, zöldségek és gyümölcsök fontos bioaktív anyagai a szekunder anyagcseretermékek közé tartozó oxigéntartalmú fenolos vegyületek, amelyek közül különös jelentőségük van az egészség megőrzésében a difenil-propán-vázat tartalmazó flavonoidoknak, amelyek közé tartoznak a flavonok, flavanonok, flavonolok, flavanonolok és glikozidjaik. Más csoportosítás szerint a bioflavonoidok közé tartoznak még a floretinek, katechinek, epikatechinek, izoflavonok, antocianidinek és a leukoantocianidinek is.

A flavonoidok hatása között jelentős eltérések figyelhetók meg, ami a molekulában található OH-, O-metil-, O-alkil-, O-glikozil-csoportok számának és elhelyezkedésének, a glikozilcsoportok jellegének, az aciláció fokának és a konjugált kettős kötések jelenlétének vagy hiányának következménye [5].

Mind a flavonoidok, mind az izoflavonoidok és az antocianidinek, illetve antocianinok rendkívül változatos formában találhatók meg az élelmiszernövények különböző részeiben. Az antocianinok 2-fenil-benzo-pirilliumsók vagy flaviliumsók polihidroxi-származékainak glikozidjai. Ezek a vegyületek napi szinten jelennek meg az élelmiszerekben, és kalkuláció szerint napi 1 g elfogyasztása ajánlott. A táplálkozástudománnyal foglalkozó szakemberek szerint a szivárvány színeinek megfelelő zöldség és gyümölcs fogyasztása lenne kívánatos a helyes étrend kialakításánál, ami azt jelenti, hogy a színtelen vagy sárga színú flavonoidok és a pirostól a lilán keresztül a kék árnyalatú antocianinok (az antocianidinek esetében a kék színárnyalat a hidroxilcsoportok, a piros színárnyalat a metoxicsoportok számának növekedésével erősödik) fogyasztására kellene fektetni a hangsúlyt, és a szervezetben „steady state” állapotra kellene törekedni $[6,7]$.

A növényi élelmiszerek fontos fenolos vegyületei közé tartoznak a fahéjsav- (például p-kumársav, kávésav, ferulasav, rozmaringsav) és benzoesav-származékok (például p-hidroxi-benzoesav, protokatechusav, vanillinsav, veratrumsav, szalicilsav), illetve a sztilbének (például a reszveratrol). A fenolsavak általában észter típusú vegyületekként, míg a fahéjsavszármazékok szabad állapotban, valamint antocianinokkal alkotott vegyületeik (acilezett antocianinok) formájában fordulnak elő [4].

A polifenolos vegyületek általában glikozidos formában találhatók a növényekben. A tápcsatornából rosszul szívódnak fel. Eredeti molekulaformájukban csupán néhány százalékban érik el a keringést és jutnak el távoli szervek sejtjeibe. Az ujjlenyomatokhoz hasonlítható bélbaktérium-populációk képesek a flavonoid-glikozidok lebontására, átalakítására, ezért az in vitro és az in vivo hatások között jelentős különbségek figyelhetők meg. A következő átalakítás a májmikroszómákon zajlik $[8,9]$.

\section{Élettani hatások}

Napról napra nő azoknak a flavonoidmolekuláknak a száma (8000 vegyület), amelyek szerkezetét meghatá- rozták, így e dolgozat keretén belül lehetetlen teljességre törekedni.

A flavonoidok biológiai hatására Szent-Györgyi és Rusznyák az 1930-as években figyelt fel, bár ók tévesen vitaminnak vélték azt a vegyületet, ami a citromlében és paprikában volt kimutatható a C-vitamin mellett, és a skorbutban jelentkező kapilláris rezisztencia csökkenését mérsékelte. Szent-Györgyi izolálta először citromléből azt a citrinnek nevezett sárga vegyületet, amiről később a szerkezetvizsgálat során kiderült, hogy két flavanon típusú vegyület, a heszperetin és eriodichtiol keveréke. Toldbunter és munkatársai igazolták az aszkorbinsav és a flavonoidok között létező szinergizmust [5]. Később igazolást nyert, hogy sok flavonoid típusú vegyület antioxidáns, és képesek az oxidált C-vitamin regenerálására.

Számos polifenolos vegyület, mint például a flavonvázas apigenin, az izoflavonol genistein, az epigallokatechin gallát, a sztilbénszármazék reszveratrol vagy a kávésav-fenetilészter hat a „gap junction”-ra, ezáltal képesek helyreállítani a sejtek közötti kommunikációt [10].

A flavan-3-olok közé tartozó katechinek, a flavanonvázas naringenin, a flavon típusú apigenin és krizin, a flavonol kvercetin, kempferol, galangin és morin, valamint az izoflavon biochanin-A támadási pontjaik a foszfolipáz A2, a ciklooxigenáz-2 (COX-2), a lipoxigenáz (LOX) és a NO-szintetáz enzimek. E hatásaik révén fékezik a gyulladásos reakciókat és közvetetten befolyásolják a jelátviteli utakat, gátolják a rákos sejtek proliferációját [10].

Scavenger tulajdonságuknak köszönhetően gátolják a szabad gyökök indukálta NADPH-oxidáz- (NOX-) aktivitást és így az angiogenezist. A vascularis endothelialis növekedési faktor (VEGF) expresszió visszaszorításával szintén fékezik a tumorok növekedését. E molekulák direkt kötődnek tirozinkináz-receptorokhoz, mitogénaktivált proteinkinázokhoz (MAPK), a foszfoinozitol-3-kinázhoz (PI3K/Akt). A sejten belüli redoxi állapotok megváltoztatásával, illetve direkt kötődéssel gátolják az NF- $\kappa$ B nukleáris faktor és az aktivált protein-1 (AP-1) szignálfehérjék sejtmagba jutását. Igazolták az $\mathrm{I} \kappa-\mathrm{B} \alpha$ inhibitor fehérje proteoszomális degradációjának gátlását is. A flavonoid-glikozidok a sejt közötti tér átalakításáért felelős mátrixmetalloproteinázok gátlásával megakadályozzák a rákos sejtek szóródását [3, 11, 12, 13, 14].

A flavonoidok megváltoztathatják a P450 enzimrendszer enzimeinek aktivitását vagy szintézisét. Az enzimrendszer enzimjei a kevésbé vízoldható flavonoidokat átalakítják vízoldható származékokká [6]. A májterápiában alkalmazott Helichrysum arenarium (homoki szalmagyopár) hatóanyagai például fokozzák a P450 enzimrendszer aktivitását $[15,16]$.

Mindezek ismeretében különösen veszélyesek lehetnek azok az étrend-kiegészítók, amelyek a napi szükségleteket jelentősen meghaladó mennyiségben tartalmaznak nutritív és nem nutritív bioaktív élelmi vagy gyógynövény-komponenseket, mert mind a betegségekkel élők, mind az egészséges emberek számára is súlyos, életveszélyes károsodásokat okozhatnak [17]. 
Meg kell említeni a katechinek jelentőségét, amely vegyületek a gyümölcsökben és levélzöldségekben, valamint nagy mennyiségben a brokkoliban is megtalálhatók, és vélhetően a brokkoli glikozinolátjaiból képződő izotiocianátok rákellenes hatását erősítik.

Slater munkásságához kötődik a májterápiában alkalmazott (+)-cianidanol-3 katechin típusú antioxidáns vegyület, amely Catergen néven hazánkban is forgalomban volt [18]. A gyógyszert később, halálos kimenetelű haemolyticus anaemiát okozó hatása miatt bevonták. Korai kutatásainkban kimutattuk, hogy a Catergen (Zyma) erős lipidperoxidációt csökkentő hatása mellett koncentrációfüggően gátolta a $\mathrm{Na}^{+} \mathrm{K}^{+}$-ATP-áz és a $\mathrm{Mg}^{++}$-ATP-áz enzimaktivitásokat, ami összefüggésbe hozható a készítmény toxikus hatásával is [19].

A májterápiában mind a mai napig sikerrel alkalmazzák a Silybum marianum (máriatövis) hatóanyagait. A silibinin a növény kaszattermésének flavonolignánja. A szilimarin a szilibin, szilidianin és szilikrisztin keveréke, amely vegyületek szerkezete a taxifolin flavononolvázhoz kapcsolódó koniferilalkohol helyzetében különbözik. E vegyületekről már az 1980-as években igazolták, hogy fokozzák az RNS-polimeráz-A aktivitását, ezáltal képesek regenerálni a májsejteket [20], de in vivo antioxidáns hatásukat elsőként kutatócsoportunk igazolta. $\mathrm{Az}$ ip. silibininkezelés hatásosan kivédte alimentáris eredetû zsírmájban a szabad gyökök membránkárosító hatását, a lipidperoxidációt, amit a májmikroszóma poliszubsztrát-monooxigenáz enzimrendszerének aktivitásváltozásán keresztül is bizonyítottunk. Megerősítésként az in vivo állatkísérletből származó májmikroszóma-preparátumok in vitro $\mathrm{Co}^{60-}$ gamma-besugárzást követő jelentős lipidperoxidációs károsodását és a következményes NADPH citokróm c reduktáz, NADH ferricianid reduktáz és $\mathrm{N}$-demetiláz enzimaktivitás csökkenését az in vivo adott silibinin szignifikáns mértékben kivédte, tehát a silibinin antioxidáns hatása igazolható volt a májban [21]. Az azóta eltelt időben kiderült, hogy a máriatövis hatóanyagai kedvezően befolyásolják a szignáltranszdukciót alkoholos májkárosodásban. A silibinin a molekuláris biológiai kutatások alapján különböző rákos megbetegedések gyógyszere lehet [22].

A füszernövényekben, gyümölcsökben és zöldségfélékben szintetizálódó, jól felszívódó hidroxi-fahéjsav-származékok, különösen a kávésav, a kutatások szerint hepatoprotektív hatásúak, mert gátolják az NF- $\kappa \mathrm{B}$ sejtmagba jutását, ezen keresztül a gyulladásos citokinek, a TNF- $\alpha$, IL-1 és IL-6, továbbá az indukálható NO-szintetáz és a COX-2 ciklooxigenáz izoenzim szintézisét [3, 23]. Késleltetik, illetve akadályozzák a fibrosis-kialakulást a pro- és antiapoptotikus fehérjék múködésén keresztül, növelve a proapoptotikus Bax gén expresszióját és csökkentve az antiapoptotikus Bcl-2 génkifejeződést, valamint a következményes fehérjeszintézist. A klorogénsav csökkenti a TGF- $\beta$-1 növekedési faktor expresszióját [24]. A klorogénsav májprotektív hatása megnyilvánul a TLR-4 (Toll-like receptor) által közvetített (TLR-4/ My-D88/
$\mathrm{NF}-\kappa \mathrm{B})$ jelátviteli útvonal gátlásán keresztül is. A rozmaringsav viszont gátolja mind a TGF- $\beta-1$, mind a CTGF növekedési faktorok expresszióját a csillagsejtekben [24, 25]. A hidroxi-fahéjsavak antioxidáns aktivitása is igazolható a membránlipidek peroxidációjának gátlásával, illetve a mieloperoxidázaktivitás csökkentésével, valamint az enzimatikus antioxidáns-védelem kulcsfontosságú enzimjei, a szuperoxid-dizmutáz (SOD) és glutation-peroxidáz (GSHPx) aktivitásának növelésével $[4,26]$. E molekuláris biológiai vizsgálati eredmények megerősítették a kutatócsoportunk által korábban közölt májprotektív hatást alimentáris eredetü zsírmájban a Cichorium intybus (mezei katáng) és Taraxacum officinale (gyermekláncfü) alkalmazásakor [27, 28].

A hazánkban népszerű, különböző meggyfajták (Prunus cerasus L.) fóbb szerves savai az almasav, borostyánkősav, borkősav másodlagos antioxidánsok, míg az aszkorbinsav antioxidáns tulajdonsága mellett prooxidáns hatásként az NF- $\kappa \mathrm{B}$ sejtmagba jutását serkenti, és ily módon a hibás gének javítását segíti [3]. Polifenolos vegyületei a flavonoidok, valamint az antocianinok [7, 29]. A magyar meggyfajtákban sokféle antocianin található, és több közülük kimagasló antocianintartalommal rendelkezik a német és amerikai meggyfajtákkal összehasonlítva, annak ellenére, hogy jelentős koncentrációkülönbségek tapasztalhatók e fajtákon belül is. A meggy antocianidin vegyületei az érésmenet végén alakulnak ki, amelyek között jelentős mennyiségben találhatók a malvidin-3-galaktozid-klorid, a pelargonidin-3,5-di-O-glükozid-klorid, a cianidin-3,5-di-O-glükozid és a delfinidin-klorid, amelyek különböző koncentrációkban gyakorlatilag az összes hazai meggyfajtában megtalálhatók [7]. A Budapesti Corvinus Egyetem munkatársaival közös kutatás keretében igazoltuk a különböző meggyfajták antioxidáns és lipidszintcsökkentő hatását alimentáris eredetû zsírmájban. Különösen jelentős volt a lipidszintcsökkentés a genisteint tartalmazó meggylé hatására [29]. Továbbá igazolást nyert a meggy vegyületeinek antibakteriális hatása is, amelyet a friss gyümölcs rágása kapcsán a száj baktériumflórájának szignifikáns csökkenésével igazoltunk [30]. Összehasonlítva a meggyfajtákat, jelentős különbségek adódtak nemcsak a bioaktív komponensek arányaiban, hanem a fémelem-koncentrációkban is, ami ráirányította a figyelmet bizonyos meggyfajták funkcionális élelmiszerré fejlesztésére, bár még hivatalosan nincs ilyen élelmiszer-kategória [31]. Az American Dietetic Association álláspontja szerint funkcionális élelmiszernek tekinthetők a klinikai vizsgálatokkal alátámasztott gazdagított, dúsított, erősített vagy átalakított élelmiszerek, amelyek a mindennapi táplálkozásba beillesztve és optimális menynyiségben fogyasztva előnyösen hatnak az egészségre.

\section{Következtetések}

Az elmúlt évek során állatkísérletes és humán vizsgálataink eredményét számos külföldi kutatócsoport is megerősítette, így nemcsak a májbetegek, hanem egyéb gast- 
rointestinalis betegségben szenvedők, sőt rákos betegek számára is megfelelő, életminőséget javító élelmiszerek fejlesztése és klinikai tesztelése válhat valóra.

Anyagi támogatás: A kapcsolódó kutatómunka a Semmelweis Egyetem Klinikai Doktori Iskola 2/1 PhDprogramja keretében kapott támogatást.

A szerző a kézirat végleges változatát elolvasta és jóváhagyta.

Érdekeltségek: A szerzőnek nincsenek érdekeltségei.

\section{Köszönetnyilvánítás}

A szerző hálával tartozik néhai Fehér János professzor úrnak, aki 1993 ban meghívta témavezetônek PhD-programjába, és köszönettel tartozik mindazoknak a munkatársaknak, akik a PhD-programban dolgoztak vagy szaktudásukkal, tanácsaikkal támogatták a kutatásokat.

\section{Irodalom}

[1] Blázovics, A., Lugasi, A., Hagymási, K., et al.: Natural antioxidants and tissue regeneration, Curative effect and reaction mechanism. In: Singh, E., Govil, J. N., Singh, V. K. (eds.): Phytochemistry and Pharmacology II. 8th ed. SCI TECH Publishing LLC, Texas, 2002.

[2] Bjelakovic, G., Nikolova, D., Gluud, L. L., et al.: Mortality in randomized trials of antioxidant supplements for primary and secondary prevention: systematic review and meta-analysis. JAMA, 2007, 297(8), 842-857.

[3] Blázovics, A.: Redox homeostasis, bioactive agents and transduction therapy. Curr. Sign. Transduct. Ther., 2007, 2(3), 226-239.

[4] Alberti, A.: Importance of dietary hydroxycinnamic acids in the therapy of liver fibrosis. [Étrendi hidroxi-fahéjsav-származékok jelentősége a májterápiában.] Orv. Hetil, 2012, 153(24), 948953. [Hungarian]

[5] Tarr, F.: Flavonoids. [A flavonoidok.] Nyíregyházi Főiskola Fizikai Tanszék, PIREMON, Debrecen-Szikgát, 2002. [Hungarian]

[6] Lugasi, A.: Potential health-protective effects of food-derived flavonoids. [Az élelmiszer eredetû flavonoidok potenciális egészségvédő hatása.] Orv. Hetil., 2000, 141(32), 1751-1760. [Hungarian]

[7] Ficzek, G., Ladányi, M., Végváry, G., et al.: Mathematical modelling of the accumulation of carbohydrates and organic acids throughout the ripening process of Hungarian sour cherry cultivars. Trees, 2015, 29(3), 797-807.

[8] Ibrabim, A. R., Abul-Hajj, Y. J.: Microbiological transformation of flavone and isoflavone. Xenobiotica, 1990, 20(4), 363-373.

[9] Baba, S., Furuta, T., Fujioka, M., et al.: Studies on drug metabolism by use of isotopes XXVII: Urinary metabolites of rutin in rats and the role of intestinal microflora in the metabolism of rutin. J. Pharm. Sci., 1983, 72(10), 1155-1158.

[10] Boik, J.: Natural compounds in cancer therapy. Oregon Medicinal Press, LLC, 2001

[11] Williams, R. J., Spencer, J. P., Rice-Evans, C.: Flavonoids: Antioxidants or signalling molecules? Free Radic. Biol. Med., 2004, 36(7), 838-849.

[12] Cheng, J. J., Huang, N. K., Chen, C. F.: Influence of flavonoids on regulation of MMPs activity in THP-1 cells. Chinese Pharm. J., 2003, 55(5), 355-360.

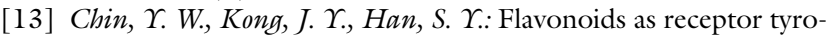
sine kinase FLT3 inhibitors. Bioorg. Med. Chem. Lett., 2013, 23(6), 1768-1770.
[14] Blázovics, A.: Small molecules in cancer therapy: cytotoxics and molecularly targeted agents. Curr. Signal Transduc. Ther., 2011, 6(1), 2-19.

[15] Cermak, R.: Effect of dietary flavonoids on pathways involved in drug metabolism. Expert Opin. Drug Metab. Toxicol., 2008, 4(1), 17-35.

[16] Czinner, E., Kéry, A., Hagymási, K., et al.: Biologically active compounds of Helichrysum arenarium (L.) Moench. Eur. J. Drug Metab. Pharmacokinet., 1999, 24(4), 309-313.

[17] Tsuji, P. A., Walle, T.: Cytotoxic effects of the dietary flavones chrysin and apigenin in a normal trout liver cell line. Chem. Biol. Interact., 2008, $171(1), 37-44$.

[18] Slater, T. F., Cheeseman, K. H., Benedetto, C., et al.: Studies on the hyperplasia ('regeneration') of the rat liver following partial hepatectomy. Changes in lipid peroxidation and general biochemical aspects. Biochem. J., 1990, 265(1), 51-59.

[19] Blázovics, A., Vereckei, A., Cornides A., et al.: The effect of (+) cyanidanol- 3 on the $\mathrm{Na}^{+} \mathrm{K}^{+} \mathrm{ATP}$-ase and $\mathrm{Mg}^{++} \mathrm{ATP}$-ase activities of the rat brain in the presence and absence of ascorbic acid. Acta Physiol. Hung., 1989, 73(1), 9-14.

[20] Sonnenbichler, J., Zetl, I.: Mechanism of action of silibinin, V. Effect of silibinin on the synthesis of ribosomal RNA, mRNA and tRNA in rat liver in vivo. [Untersuchungen zum Wirkungsmechanismus von Silibinin, V. Einfluss von Silibinin auf die Synthese ribosomaler RNA, mRNA und tRNA in Ratternlebern in vivo.] Hoppe Seylers Z. Physiol. Chem., 1984, 365(5), 555566. [Germain]

[21] Blázovics, A., Fehér, J.: Natural antioxidants and tissue regeneration (Beneficial effect and mechanism of reaction II). [Természetes antioxidánsok és szöveti regeneráció (Gyógyhatás és reakciómechanizmus II.).] Fitoterápia, 1995, 1(4), 171-176. [Hungarian]

[22] Cheung, C. W., Gibbons, N., Johnson, D. W., et al.: Silibinin - a promising new treatment for cancer. Anticancer Agents Med. Chem., 2010, 10(3), 186-195.

[23] Ohara, K., Uchida, A., Nagasaka, R., et al.: The effects of hydroxycinnamic acid derivatives on adiponectin secretion. Phytomedicine, 2009, 16(2-3), 130-137.

[24] Abou-Shady, M., Friess, H., Zimmermann, A., et al.: Connective tissue growth factor in human liver cirrhosis. Liver, 2000, 20(4), 296-304.

[25] Shi, H., Dong, L., Jiang, J., et al.: Chlorogenic acid reduces liver inflammation and fibrosis through inhibition of toll-like receptor 4 signaling pathway. Toxicology, 2013, 303, 107-114.

[26] Gülçin, I.: Antioxidant activity of caffeic acid (3,4-dihydroxycinnamic acid). Toxicology, 2006, 217(2-3), 213-220.

[27] Kocsis, I., Szentmihályi, K., Rapavi, E., et al.: Effect of Cichorium intybus (L.) on the redox balance and metal ion content of fatty liver in hyperlipidemic rats. Trace Elements and Electrolytes, 2004, 21(4), 262-268.

[28] Hagymási, K., Blázovics, A., Lugasi, A., et al.: In vitro antioxidant evaluation of dandelion (Taraxacum officinale Web.) water extract. Acta Aliment. Hung., 2000, 29(1), 1-7.

[29] Hegedüs, A., Papp, N., Abrankó, L., et al.: Role of fruits in nutrition. In: Blázovics, A., Mézes, M. (eds.): Natural agents in modern medicine. [Gyümölcsök szerepe a korszerú táplálkozásban. In: Blázovics, A., Mézes, M. (szerk.): Természetes hatóanyagok a modern orvoslásban.] Szent István Egyetemi Kiadó, Gödöllő, 2014. [Hungarian]

[30] Hevesi, M., Blázovics, A., Kállay, E., et al.: Biological activity of sour cherry fruits on the bacterial flora of human saliva in vitro. Food Technol. Biotechnol., 2012, 50(1), 117-122.

[31] Süle, K., Fehér, E., Blázovics, A., et al.: Changes in metal homeostasis in experimentally induced fatty liver by the effect of sour cherry consumption. Eur. Chem. Bull., 2012, 1(9), 360-363.

(Blázovics Anna dr., Budapest, Üllői út 26., 1085 e-mail: blazovics.anna@pharma.semmelweis-univ.hu) 